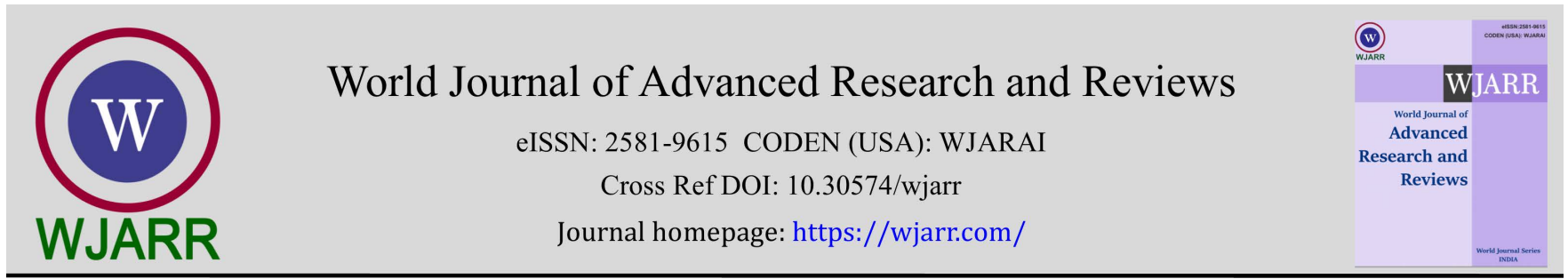

(RESEARCH ARTiClE)

\title{
Geophysical investigation of the effects of waste dump on groundwater quality in Rukpokwu, Port Harcourt Metropolis
}

\author{
Nwankwoala $\mathrm{HO}{ }^{1, *}$, Osayande $\mathrm{AD}^{2}$ and Mba JC ${ }^{1}$ \\ ${ }^{1}$ Department of Geology, University of Port Harcourt, Nigeria. \\ 2 Department of Geology and Mining Technology, University of Port Harcourt, Nigeria.
}

World Journal of Advanced Research and Reviews, 2022, 13(01), 583-589

Publication history: Received on 18 December 2021; revised on 20 January 2022; accepted on 22 January 2022

Article DOI: https://doi.org/10.30574/wjarr.2022.13.1.0074

\begin{abstract}
Vertical Electrical Sounding (VES) was carried out in Rukpokwu, Obio/Akpor Local Government Area, Rivers State, Nigeria to investigate the effect of waste dump on groundwater quality in the study area. An ABEM SAS 300 terrameter was used. Schlumberger configuration was adopted for the sounding to acquire a 4 point data, and at Rukpokwu adjudged to be free from waste dumps which served as control. The result of the resistivity survey was interpreted by IPI2WIN computer software, revealing the subsurface lithology, thickness of lithology, prolific auriferous zones, curve types and zones of contamination. The Niger Delta has a shallow water table which makes it prone to easy contamination. Different resistivity values were obtained; high resistivity values are an indication of uncontaminated subsurface lithologic zones while low resistivity values are an indication of contaminated subsurface lithologic zones as a result of dissolved ions and metals from waste dumps decomposing through biochemical reactions, hydrolysis, oxidation and reduction processes which subsequently leads to the formation of leachate. This leachate is in hydraulic continuity with groundwater flow which eventually leads to groundwater contamination. Therefore a geophysical survey is essential and necessary before a borehole drilling project is carried out in order to ascertain the depth to prolific aquifer which will give potable water free from contamination.
\end{abstract}

Keywords: Geophysical investigation; Resistivity; Waste Dump; Groundwater; Rukpokwu; Rivers State

\section{Introduction}

Waste (industrial and domestic) has been defined as useless unwanted materials which arise from human activities and are not free flowing[1].Wastes when well managed could be harnessed into a profitable channel for mankind but then poor management of solid waste has resulted to a lot of disastrous effects such as groundwater contamination. Waste dump sites have become one of the major environmental problems in most Nigerian cities; for instance Port Harcourt.The importance of groundwater as a valuable source of portable water cannot be over emphasized. Groundwater forms the most important natural resources of any region and compliments surface sources in the provision of portable water for domestic and industrial applications. The continuous contamination of groundwater gradually leads to its pollution. Ground water pollution may occur due to the contamination of leachate from waste dump [2].Ground water provides a medium through which wastes mostly organics can undergo degradation into simpler forms through biochemical reactions involving dissolution, oxidation, and reduction processes. These wastes being organic have organic carbon present in them largely in the form of fulvic acids [3] which migrate downward and contaminate the groundwater. During the peak of the rainy season, dumpsites are covered by flood water and this contributes to the formation of leachate. It is this leachate that forms a "plume" that moves outwards and downwards into the surrounding and underlying aquifers [4].

\footnotetext{
${ }^{*}$ Corresponding author: Nwankwoala HO

Department of Geology, University of Port Harcourt, Nigeria.

Copyright (C) 2022 Author(s) retain the copyright of this article. This article is published under the terms of the Creative Commons Attribution Liscense 4.0.
} 
In groundwater investigations, groundwater contamination challenge has been overcome by utilizing geophysical technique prior to the drilling of boreholes for groundwater extractions. Geoelectric method has been found very suitable for this kind of environmental study. This is due to the fact that generally, ionic concentration of leachate is much higher than that of groundwater and so when the leachate enters the aquifer, it results in a large contrast in electrical properties and this method helps in identifying these zones as an anomaly which enables the leachate plume to be detected.The electrical resistivity method (DC method) particularly vertical electrical sounding (VES) serves as the cheap and fastest means for groundwater studies. This research therefore adopts the use of vertical electrical sounding (VES).The aim of this study is to determine the effect of waste dump on groundwater quality in the study area using a geophysical method, electrical resistivity, vertical electrical sounding (VES).

\section{Location and Geology of the Study Area}

\subsection{Description of the Studied Area}

The study area is a major Nigerian Upstream Regulatory Commission (NURC) formerly Department of Petroleum Resources (DPR) approved dumpsite located in Obio-Akpor Local Government Area, along the international Airport Road, Port Harcourt, Rivers State Nigeria.It is accessible through the International Airport Road, Obio-Akpor Local Government Area. There's a DPR signpost serving as a landmark.

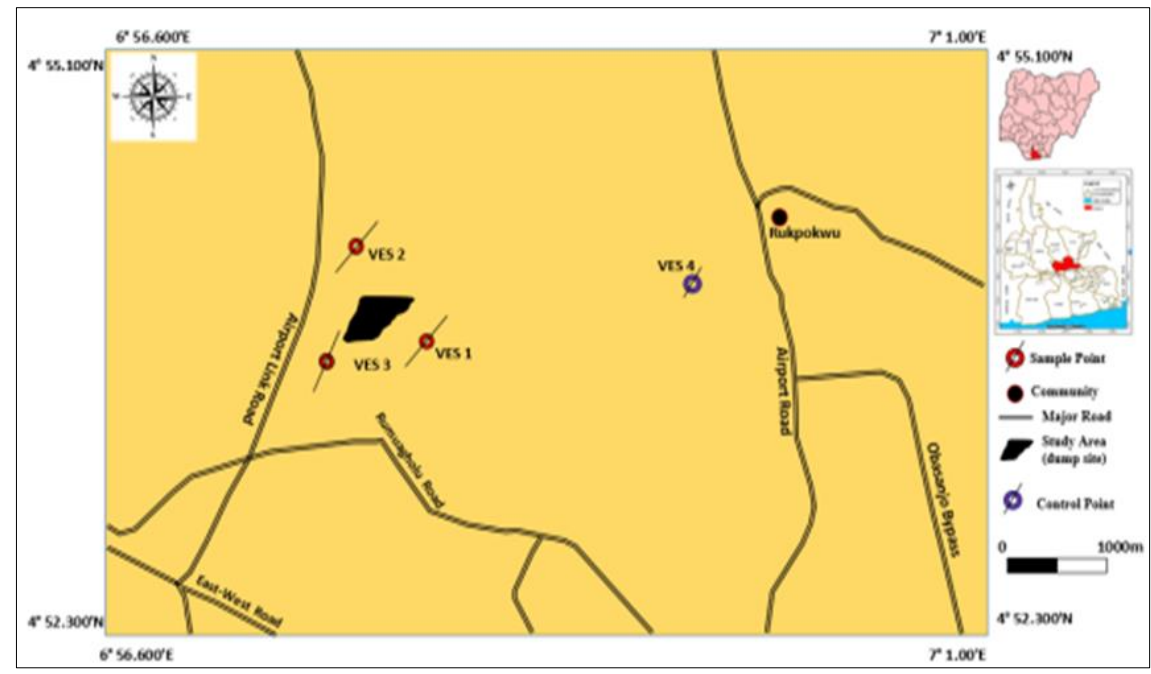

Figure 1 Map of the studied area

\subsection{Relief and Drainage}

The relief of the area is quite low; the land surface of the area is generally less than $20 \mathrm{~m}$ above sea level.

\subsection{Climate and Vegetation}

The studied area, experiences a tropical climate characterized by two distinct seasons; the wet season (April to midAugust, September to mid-November) and dry season (November till March) usually with sparse rainfall in-between [5]. The rainfall exhibits a double maxima regime with peaks in July and September, with a little dry season in August. In the dry season, high evapotranspiration rate induced by dry conditions helps to increase water losses in the region [6].The vegetation of the Niger Delta is classified into 2 main regions namely; The swamp forest region and the rainforest region, The swamp forest is further subdivided into two (2) fresh water and salt water swamp which divides the Niger Delta into these vegetation regions. The characteristic vegetation of the salt water swamp forest is the presence of mangrove trees in its varieties. The secondary forest on the other hand represents the vegetation type derived from other activities that combined to degrade the original forest vegetation.

\subsection{Hydrogeology of the Study Area}

The studied area falls within the Benin Formation. The formation has been identified as fresh water bearing sand;[7][8] and all aquifers in the deltaic region occurs within this lithostratigraphic unit. [9] Have been able to identify five aquifer horizons in the Niger Delta. 
The study area falls within the Benin Formation. The formation has been identified as fresh water bearing sand [7][8] and all aquifers in the deltaic region occurs within this lithostratigraphic unit. [9] Have been able to identify five aquifer horizons in the Delta as presented in Table 2The shallow unconfined aquifers are localized while the deeper ones are laterally more extensive. Generally, the depth to the water table in the Delta increases northwards from $<1 \mathrm{~m}$ at the coast to $16 \mathrm{~m}$ at the northeast section [10]. The regional groundwater flow direction in deep aquifers is generally southwards towards the Atlantic Ocean whilst the local flow direction in shallow aquifers is generally towards the nearest river or stream[10].

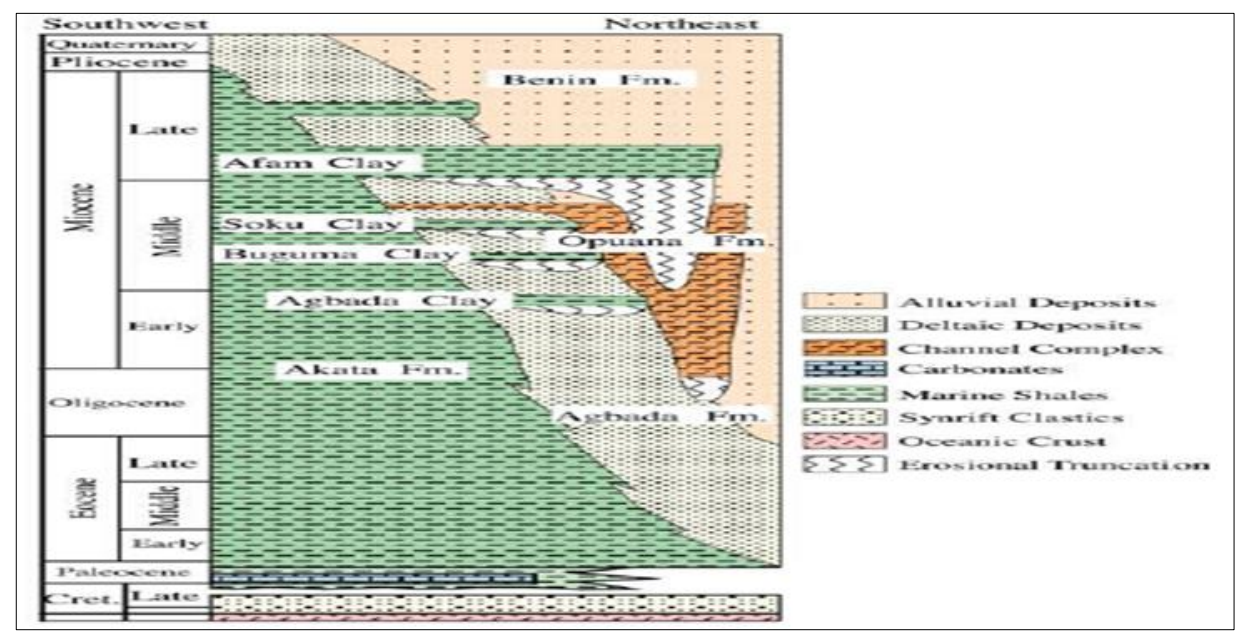

Figure 2 Stratigraphic Column of Niger Delta Formations [11]

The Niger Delta consists of three stratigraphic units; the base of the Delta is the Akata Formation (Paleocene-Eocene) which consists of marine shales and silts. The Agbada Formation (Eocene-Oligocene) overlies the Akata Formation and is made up of paralic sequence consisting of sands and shales. Their lateral equivalents at the surface are the OgwashiAsaba Formation and Ameki Formation of Eocene-Oligocene age ([7], [12]. Above the Agbada Formation is the Benin Formation (Oligocene-Recent) which comprises of continental/fluvial sand sand gravels. The Benin Formation is however overlain by the QuatenarySombreiro-Warri Deltaic Plain Deposits which are 40 - $150 \mathrm{~m}$ thick, an unconfinedaquifer sequence comprising rapidly alternating sequences of sand and silt/clay, with the latter becoming increasingly prominent seawards, are thought to have been laid down during the Quaternary interglacial marine transgression[13];[14];[9]. The hydraulic conductivity of the sands varies from $3.8 \times 10-3 \mathrm{~m} / \mathrm{s}$ to $9 \times 10-2 \mathrm{~m} / \mathrm{s}$ which indicates potentially productive aquifer[15].

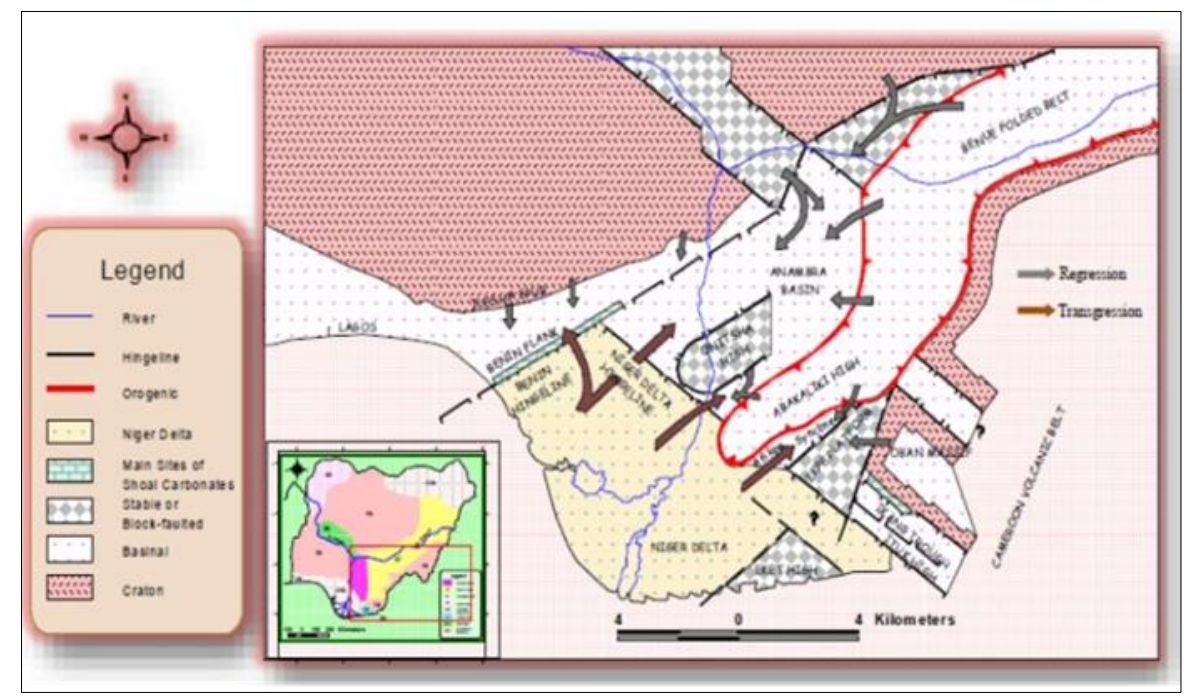

Figure 3 Tectonic Map Showing the Niger Delta (Modified after Kogbe, 1989) 


\section{Materials and methods}

\subsection{Surface Investigation}

Four (4) dc-resistivity vertical electrical sounding (VES) soundings were run in Schlumberger array with an ABEM SAS 300 model Terrameter using current electrode spacing (AB) ranging from $2 \mathrm{~m}-300 \mathrm{~m}$. Three points was acquired around the dumpsite (NURC formerly DPR Approved dumpsite) while the fourth point, was approximately $2 \mathrm{~km}$ metres away from the Dumpsite. First point was around an excavated part the dumpsite (burrow pit), second point was around a stagnant body of filthy water (leachate) and the third point was very close to Dump, where fresh dumps were being deposited on the already existing dump while the survey was been carried out. The fourth VES was carried out $2 \mathrm{~km}$ away from the dump site adjudged to be free from contamination. The current electrode (C1C2) is moved outward symmetrically, keeping (P1P2) fixed at the centre. The adopted configuration entails not moving the potential electrode until the potential difference becomes too small to be measured accurately. The initial interpretation of the VES data was accomplished using conventional partial curve matching techniques utilizing two-layer master curves [16] and their corresponding auxiliary point diagrams [17]. The resistivities and thicknesses obtained were used in a computer programme for refining the partial curve matching interpretative results which reduced errors to acceptable levels [18]. The programme, win Resist version 1.0 based on the work of [19] was used.

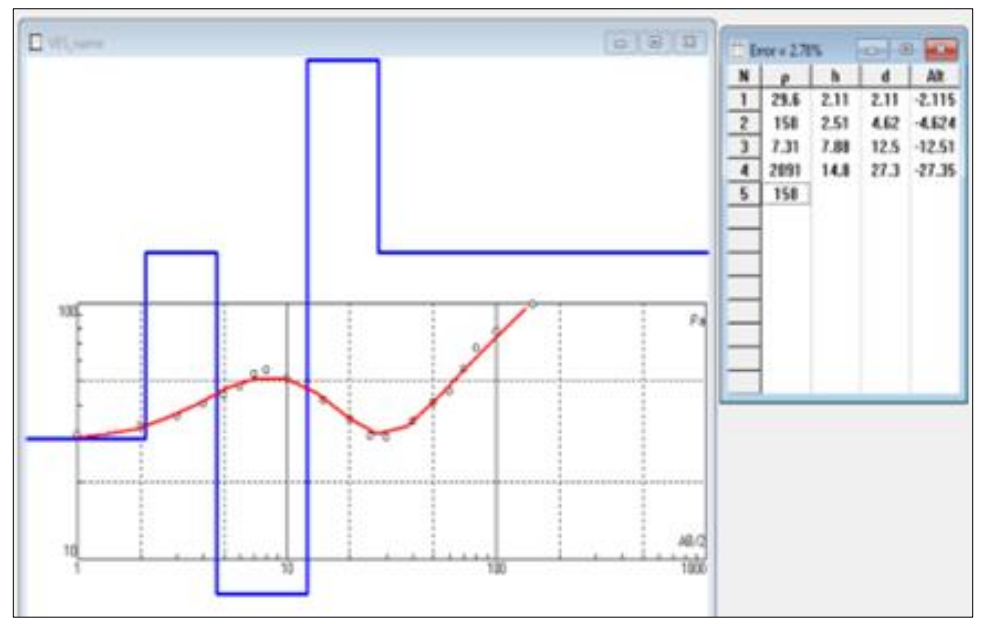

Figure 4 Typical VES curves for the studied area location 1

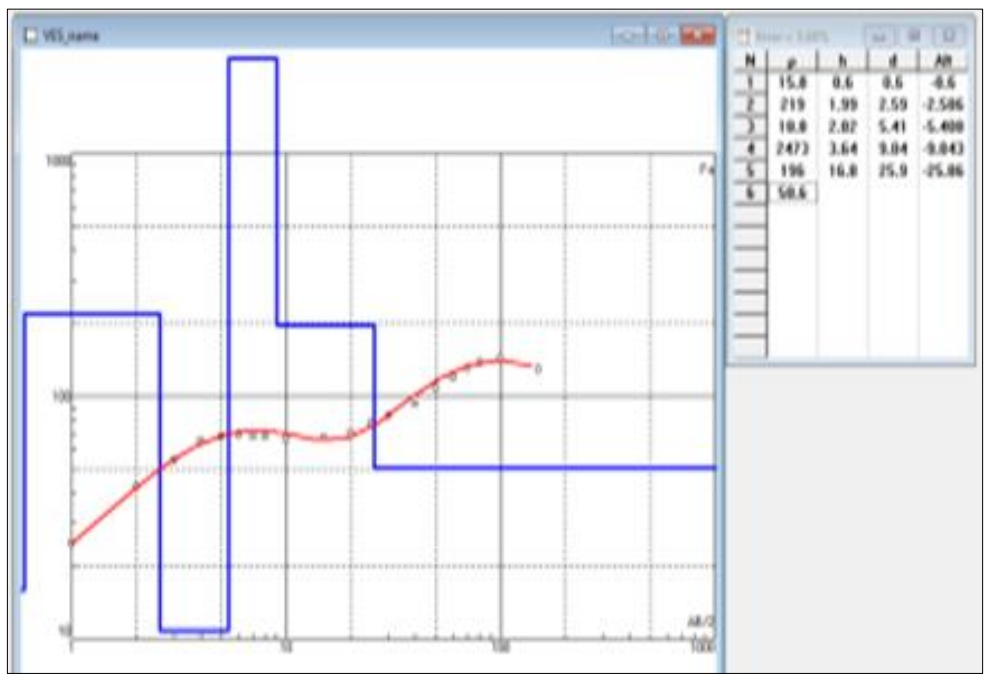

Figure 5 Typical VES curves for the studied area location 2 


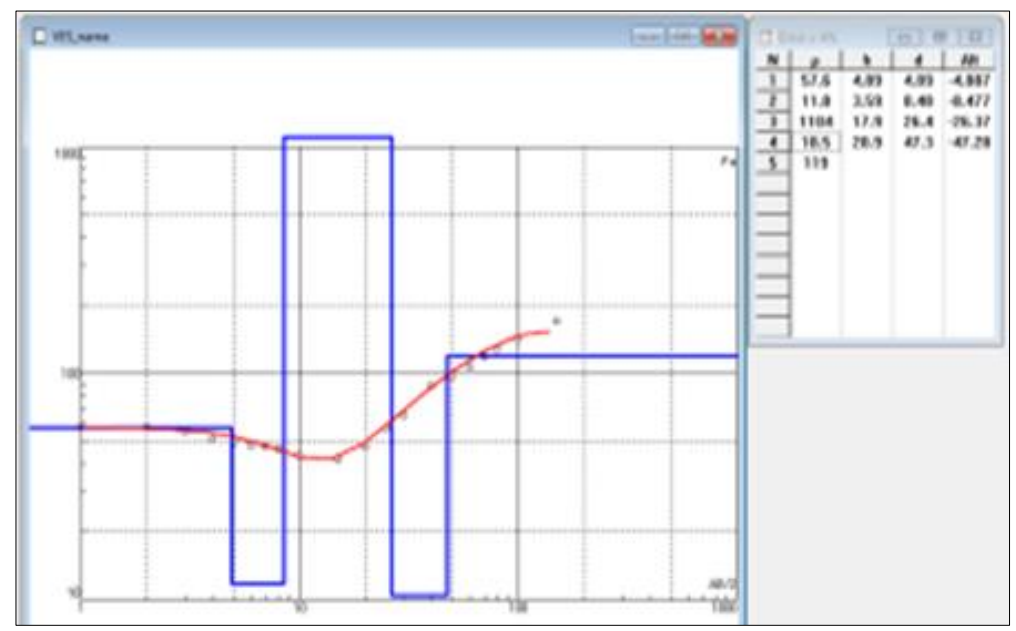

Figure 6 Typical VES curves for the studied area location 3

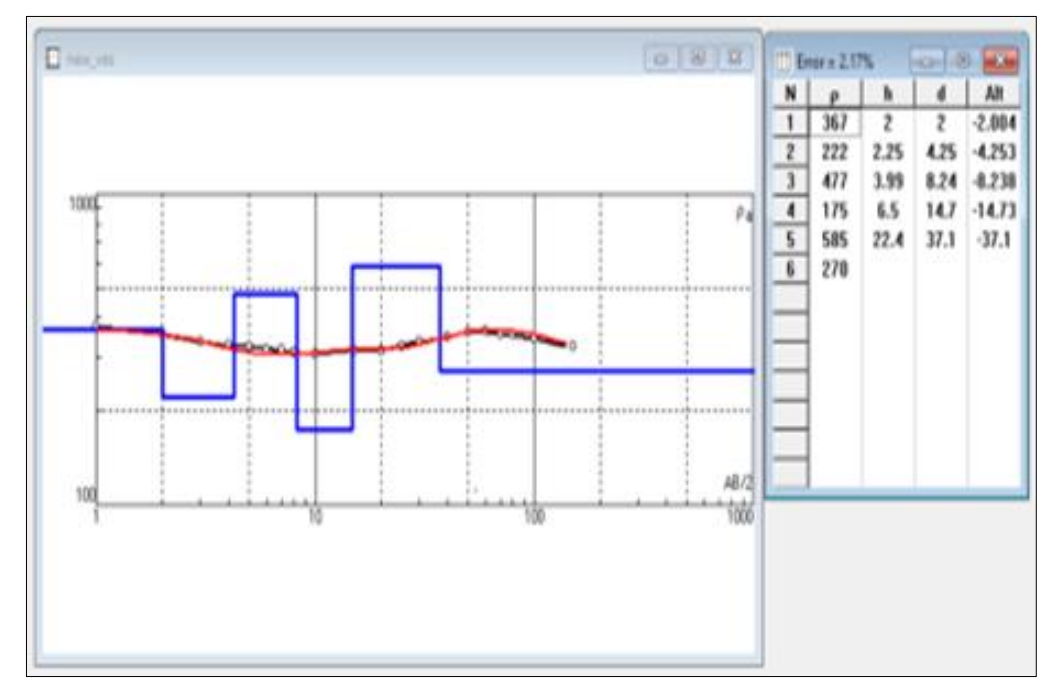

Figure 7 Typical VES curves for the studied area location 4

\section{Results and discussion}

The depth sounding curves (figure 4, 5, 6 \& 7) shows that there are 4 layers and 5 layers of the subsurface materials with different resistivity values respectively. Resistivity values from VES 1 to VES 4 vary with progressive electrode spacing (current and potential electrode). The low resistivity values of $7.31 \Omega \mathrm{m}, 10.8 \Omega \mathrm{m}, 11.8 \Omega \mathrm{m}$ from VES 1 , VES 2 and VES 3 indicates that the layers associated with these values is polluted,[20]. This is as a result of leachate plumes reacting with ground water in the subsurface. Leachates usually contain biological and chemical constituents. Organic matter decomposing under aerobic condition produces carbon dioxide which acts with leaching water to form carbonic acid $\mathrm{CO} 2+\mathrm{H} 2 \mathrm{O}-------\mathrm{H} 2 \mathrm{CO}$. This in turn acts upon metals in the refuse and other calcareous materials in the soils and rocks resulting in increasing hardness and conductivity of contaminated water [21].The depth and thickness of the fourth layer of VES 1 , the fifth layer of VES 2, the fourth layer of VES 3, with resistivity values of $158 \Omega \mathrm{m}, 50 \Omega \mathrm{m}$, and $119 \Omega \mathrm{m}$ respectively could not possibly be reached, occurring after depths of $27.3 \mathrm{~m}, 25.90 \mathrm{~m}$, and $47.3 \mathrm{~m}$ and as such suspected to be a fresh water uncontaminated layer. VES 4 which serves as control and adjudged to be from waste has its highest resistivity value to be $585.00 \Omega \mathrm{m}$ at the fifth layer, is also suspected to be a fresh water zone, with respect to the high resistivity value invariably implying low conductivity of the fifth layer. The fourth, third and fourth layer of VES 1 , VES 2 and VES 3 at the dumpsite is polluted due to their low resistivity values. 


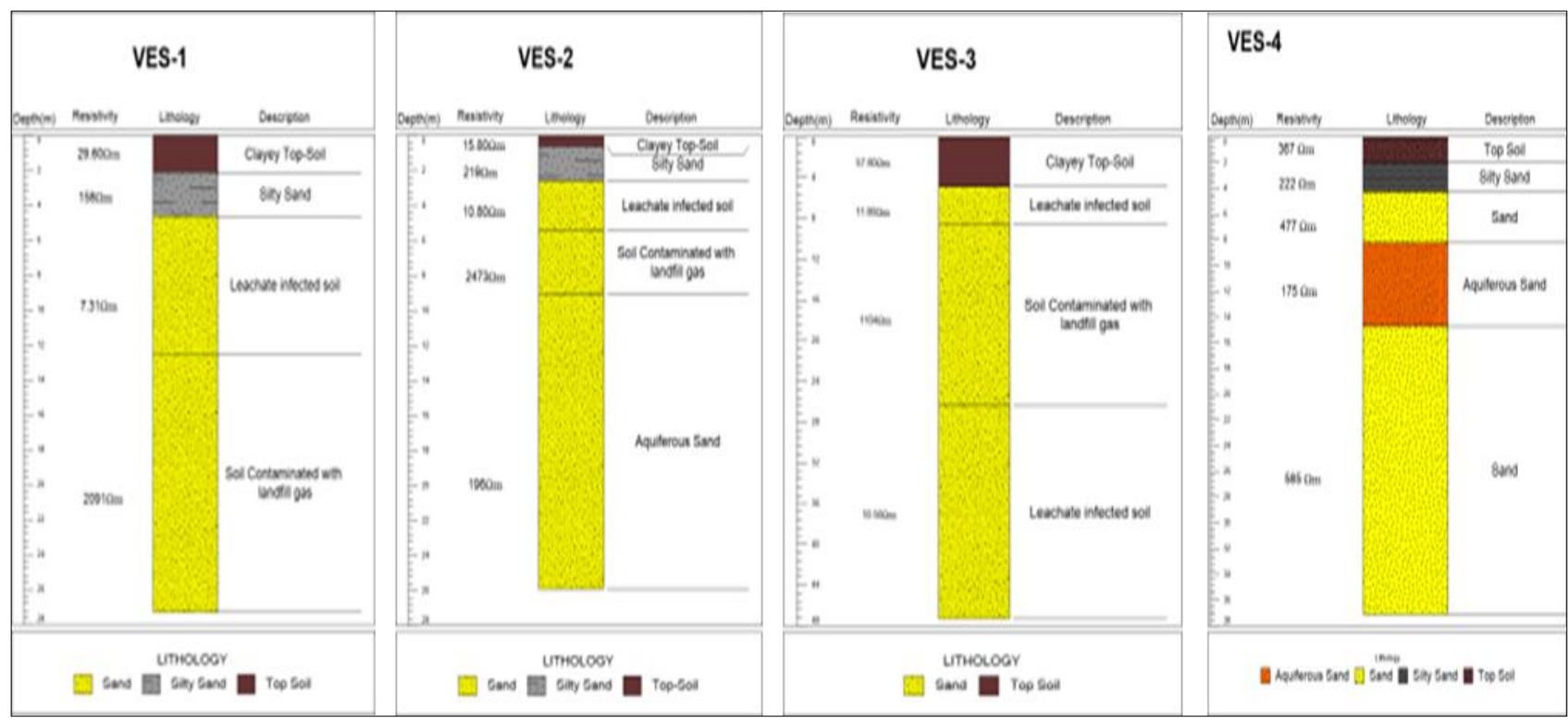

Figure 8, 9, 10 \& 11 Geoelectrical section of ves1, 2, 3, 4 respectively

\section{Conclusion}

A surface and subsurface resistivity survey was carried out with the aim of evaluating the effect of waste dump on groundwater potential and its quality. The surface study revealed four and five geoelectric layers. The geoelectical sections VES 1 and VES 3 revealed 4 layers respectively in which leachate infected soil and soil contaminated with landfill were in the third layers of VES 1 (at the average depth of $7.31 \mathrm{~m}$ ) and fourth layers (at the average depth of $2091 \mathrm{~m}$ ) respectively while leachates infected soil and soil contaminated with landfill were on the second layer of VES 3 (at the average depth of $11.80 \mathrm{~m}$ ) and in the third layers(at the average depth of $11.04 \mathrm{~m}$ ) respectively. Interpretation of geoelectric sounding of refuse dumpsite has yielded information on groundwater contamination as indicated by the values of subsurface resistivity and thickness. The essence of this study is to show that boreholes sited at these areas are likely contaminated and therefore to access potable water in this area, a geophysical data is highly recommended. Geolectrical resistivity sounding method has been no doubt helpful in the detection of groundwater contamination within the study area and as such serves as a very useful tool in groundwater studies, therefore before any drilling project is done, a geophysical resistivity assessment of the area needs to be carried out in order to ascertain water quality in the environment as this would serve as a guide for the success of drilling potable and sustainable water supply.

\section{Compliance with ethical standards}

\section{Acknowledgments}

The Authors are grateful to Prof T.K.S Abam (Senior Lecturer in Geology Department, Rivers State University) and Dr. J.I Nwosu (Senior Lecturer in Geology Department, University of Port Harcourt) for their encouragements.

\section{Disclosure of conflict of interest}

The Authors declares that there is no conflict of interest.

\section{References}

[1] Federal Environmental Protection Agency (FEPA). Corporate Profile.Metro Prints Ltd, Port Harcourt. 1995.

[2] Makeig KS. National buffers for sludge leachates Stabilization of groundwater; Geophysics. 1982; 20(2): 420-429.

[3] Taylor R, Allen A. Nature and Subject in Landfill. Impact Proble (Memorandum).2001.

[4] Carpenter PJ, Ding A, Cheng L. Identifying Groundwater Contamination Using Resistivity Surveys at a Landfill near Maoming, China. Nature Education Knowledge. 2012; 3(7): 20. 
[5] Ofoma, A.E., Unwuka, O.S., and Egbu, O.S.,Ground water quality in Lekwesi/Umuchieze Area. Southeastern Nigeria. The pacific Journal of Science and technology2005; 6(2): 170- 176.

[6] Etu-Efeotor J0,Odigi MI. Water supply problems in the Eastern Niger Delta. Journal of Mining Geol. 1983; 20 (1\& 2): 183-193.

[7] Short KC,Stauble AJ. Outline Geology of Niger Delta. AAPG Bull. 1967; 51: 761-779.

[8] Amajor LC, Ofoegbu CO. Intra-continental-Plate Alkaline Basaltic volcanism, Uturu, Southern Benue Trough, Nigeria". ActaUni.Carolinae-Geologica. 1988; 2: 233-242.

[9] Etu-Efeotor JO,Akpokodje EG. Aquifer systems of the Niger Delta. Journal of Mining Geology. 1990; 26(2): 279285.

[10] Giadom FD, Akpokodje EG, Tse AC. Determination of migration rates of contaminants in a hydrocarbon-polluted site using non-reactive tracer test in the Niger Delta, Nigeria. Environ Earth Sci, Springer-Verlag Berlin Heidelberg. 2015.

[11] Doust H, Omatsola E, Niger Delta In, Edwards JD, Santogrossi PA. Eds., Divergent/Passive Margin Basins: AAPG Memoir 48: Tulsa, American Association of Petroleum Geologists. 1990; 48: 239-248.

[12] Asseez, OL, Review of the stratigraphy, sedimentation and structure of the Niger Delta. In: Kogbe (ed) Geology of Nigeria,Rock View (Nig.) Ltd., Jos, 1989: 311-324

[13] Oomkens, O., Lithofacies relations in the Late Quaternary Niger Delta complex. Sedimetology,1974;21:195-222

[14] Durotoye, B, Quaternary sediments in Nigeria: In:Kogbe (ed) Geology of Nigeria, Rock View (Nig.) Ltd., Jos, 1989: 311-324

[15] Akpoborie IA, Ekakite OA, Adaikpoh EO. The quality of groundwater from Dug wells in parts of the western Niger Delta. Knowledge Review. 2000; 2(5): 72-75.

[16] Koefoed O.Geosounding Principle-1. Elsevier,Amsterdam. 1979; 170 - 181.

[17] Orellana E,Mooney HM. Master tables and curves for vertical electrical over layered structures. Interscience, Madrid. 1966; 193.

[18] Barker RD. Depth of investigation of collinear symmetrical four-electrode arrays. Geophysics. 1989; 54: 10311037.

[19] Van Der Velpen, B, and Minguet, Th. Physico-Chemical Treatments:washing of polluted Soils; Traitement physicochimique: lavage des sols pollutes.France: N.p.,2004.Web

[20] Reynolds JM. An Introduction to Applied and Environmental Geophysics. John Wiley and Sons New York. 1977; 796.

[21] Schneider WA. Integral formulation for migration in two and three dimensions: Geophysics. 1978; 43: 4976. 